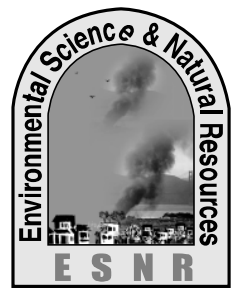

J. Environ. Sci. \& Natural Resources, 6(2): 177 -180, 2013

ISSN 1999-7361

\title{
Assessment of Ground Water Quality at Mawlana Bhashani Science and Technology University Campus, Tangail, Bangladesh
}

\author{
M. N. Uddin ${ }^{1}$, M. M. Rahaman ${ }^{2}$ and M. S. Mondal ${ }^{3}$ \\ ${ }^{1,3}$ Institute of Water and Flood Management (IWFM), Bangladesh University of Engineering and \\ Technology (BUET), Dhaka-1000. \\ ${ }^{2}$ Dept of Environmental Science and Resources Management (ESRM), Mawlana Bhshani Science and
} Technology University (MBSTU)

\begin{abstract}
An investigation was carried out to determine the $\mathrm{pH}, \mathrm{EC}, \mathrm{TDS}, \mathrm{As}, \mathrm{Mn}, \mathrm{Fe}$, and $\mathrm{Pb}$ in the ground water at Mawlana Bhashani Science and Technology University Campus. The water samples were collected from the tube well and reserved tank at 6 different locations in February, 2012 and August, 2012 covering hall and academic establishment. The concentration of $\mathrm{pH}, \mathrm{EC}$, TDS, As, Mn, Fe, and Pb varied 6.4-6.8, 377.5-590 $\mathrm{scm}^{-1}$, 192.5-282ppm, 0.00018-0.0159ppm, 0.07-3.825ppm, 0.00-5. 618 ppm and 0.00- $0.00006 \mathrm{ppm}$ respectively. According to the standard of drinking water $\mathrm{pH}$, EC, TDS, As, and Pb toxicity were not detected and in some cases the concentrations of $\mathrm{Mn}$ and Fe were considered as toxicants due to their higher concentrations. Correlation and seasonal fluctuation were also considered in this study. The dry season sample contained higher amount of trace metals than that of wet season.
\end{abstract}

Key word: Ground Water, Water quality

\section{Introduction}

Water is an inevitable component of natural resources and plays an important role to serve as many purposes like drinking, irrigation, aquaculture and livestock usages. It is needless to say that without enough good water our survival will be threatened. We have plenty of both surface and ground water supply to support the entire population in Bangladesh. In fact, after human resources water is the most abundant resource in Bangladesh (Azad, 2003). Bangladesh comprises the third largest source of fresh water to discharge to the ocean (Ali, 2002).

About $97 \%$ of the population of Bangladesh use tube well water for drinking and cooking purposes (D.C.H, 1998). Bangladesh has about 1.8 million hands tubewell for supplying drinking water from underground sources to meet the need of 124 million people (Sattar, 1996). Water is contaminated by two ways such as natural and artificial. Generally ground water is clean and seems to be pure but it has never found in its originated state. All ground water contain salt in solution and higher concentrations of dissolved constituents are found than in surface water because of the greater exposure to soluble materials in geologic strata. Soluble salts in ground water and surface water were originated from weathering of rocks and minerals. The quality of water is judged by its total salt concentration. The concentration of toxic substances such as $\mathrm{As}, \mathrm{Cd}, \mathrm{Cr}, \mathrm{Pb}, \mathrm{Co}, \mathrm{Mn}, \mathrm{Fe}, \mathrm{Mo}$ etc. are varied with salt concentration. Most heavy metals such as $\mathrm{Cd}, \mathrm{Cr}, \mathrm{As}, \mathrm{Cu}, \mathrm{Pb}, \mathrm{Ni}, \mathrm{Ar}, \mathrm{Hg}, \mathrm{Mo}$, $\mathrm{Sn}, \mathrm{Sb}$ etc. are consistently presents in small amounts in the environment (soil, water, crop etc.) but they are potentially and can affect many species of plants and animals as water soluble concentrations lower than 1.0 ppm (Sattar, 1996).

Now a day it is very hard to get fresh water and safe drinking water due to water pollution. The world now faces a water crisis. Water shortage, water pollution, food and environmental (pond, lake, river, etc.) contaminations are the great problems which cause food shortage, increasing contagious diseases and occasion international dispute over limited water resource.

\section{Objectives of the study}

Mawlana Bhashani Science and Technology University campus is an important place for educational purposes. About 5000 people are staying in this campus. So the drinking water is an important factor for this campus, because contaminated water directly affects the health of the inhabitant. For this reason the present study was conducted with the following objectives:

1. To assess the chemical properties $(\mathrm{pH}, \mathrm{EC}$, and TDS) of ground water at MBSTU campus.

2. To assess the concentration of heavy metal like $\mathrm{Pb}, \mathrm{As}, \mathrm{Mn}$, and $\mathrm{Fe}$ in ground water.

3. To evaluate the change of quality due to seasonal variation.

\section{Materials and Methods}

Samples were collected from the different water tank and tube well at MBSTU campus in $500 \mathrm{ml}$ bottle. This bottle was cleaned with dilute hydrochloric acid and then washed with tap water followed by distilled water. After collecting the bottles containing samples 
were sealed immediately to avoid exposure to air. To provide necessary information for each sample such as date of collection, location, source of water, etc was recorded in note book and each sample collected in bottle was leveled separately with a unique identification number. Then the water quality parameters such as $\mathrm{pH}$, Electric Conductivity (EC) and total dissolved sold (TDS) were detected by respective digital meter. Then the water was transferred into another $100 \mathrm{ml}$ bottle which contained $10 \mathrm{ml} 2 \mathrm{M}$ hydrochloric acid solution to protect water samples from any fungal and other pathogenic attack then sample was tested by Atomic Spectrophotometer to determine the concentration of arsenic (As), Lead $(\mathrm{Pb})$, Iron $(\mathrm{Fe})$, and Manganese ( $\mathrm{Mn})$.

\section{Result and Discussion}

Concentration and Seasonal variation of $p^{H}$,TDS, $\mathrm{EC}, \mathrm{Mn}, \mathrm{Fe}, \mathrm{Pb}$ and As with their standard level

The $\mathrm{pH}$ value of different season was studied to compare with the standard level of WHO recommendations. In dry season the mean value was 6.48 and wet season it was 6.76 which were within their standard level $(6.5-8.5)$ that indicate the water was fit for consumption. The $\mathrm{pH}$ of water affects the solubility of many toxic chemical. As acidity increases, most metals become more water soluble and more toxic (Table 1).

Table 1. Seasonal variation of $\mathrm{p}^{\mathrm{H}}$, TDS, EC, Mn, Fe, $\mathrm{Pb}$ and As with WHO standard limit

$$
\text { Seasonal variation (Observed in ppm) WHO Standards }
$$

\begin{tabular}{ccccc} 
Parameters & Wet season $(\mathrm{ppm})$ & Dry season $(\mathrm{ppm})$ & Lower limit(ppm) & $\begin{array}{c}\text { Upper limit } \\
(\mathrm{ppm})\end{array}$ \\
\cline { 2 - 5 } $\mathbf{P}^{\mathrm{H}}$ & 6.48 & 6.76 & 6.5 & 8.5 \\
\hline $\mathrm{TDS}$ & 218.16 & 269.16 & 500 \\
\hline $\mathrm{EC}$ & 522.16 & 430.33 & 500 \\
\hline $\mathrm{Mn}$ & 0.395 & 1.54 & 0.5 \\
\hline $\mathrm{Fe}$ & 3.98 & 1.47 & 1 \\
\hline $\mathrm{Pb}$ & 0.0000063 & 0.000061 & 0.01 \\
\hline $\mathrm{As}$ & 0.006 & 0.005 & 0.05
\end{tabular}

The TDS value of different season was studied to compare with the standard level. In dry season the mean value was $269.16 \mathrm{ppm}$ and wet season it was $218.16 \mathrm{ppm}$ which was lower than their standard level $(500 \mathrm{ppm})$ which indicates the water is good for consumption (Table 1). The EC value of different season was studied to compare with the standard level. In dry season the mean value was $430.33 \mu \mathrm{scm}^{-1}$ and wet season was $522.16 \mu \mathrm{scm}^{-1}$. In dry season it was under standard level (500), in case of wet season the value exceeded the standard level (Table 1).

EC value in MBSTU campus is comparatively high due to high concentration of different ions presence in this ground water. The Mn value of dry and wet season was studied to compare with the standard level. In dry season the mean value was $1.5 \mathrm{ppm}$ that exceeded the acceptable level $(0.5 \mathrm{ppm})$ and wet season was $0.395 \mathrm{ppm}$ which was below the standard level (0.5ppm) (Table 1). In dry season the Mn concentration is high in MBSTU campus due to less volume of water increases the higher concentration of metallic dissolve.

The $\mathrm{Fe}$ value of different season was studied to compare with the standard level. In dry season the mean value was $1.47 \mathrm{ppm}$ and in wet season it was $3.98 \mathrm{ppm}$ which exceeded their standard level (1ppm) which indicates the water is not fit for drinking purpose (Table 1). Fe concentration is high in MBSTU campus due to higher Iron presence in ground. The $\mathrm{Pb}$ value of different season was studied to compare with the standard level. In dry season the mean value was $0.000061 \mathrm{ppm}$ and in wet season it was $0.0000063 \mathrm{ppm}$ which was lower than their standard levels $(0.01 \mathrm{ppm})$ which indicate the water is fit for drinking purpose (Table 1). 
$\mathrm{Pb}$ concentration is comparatively low in MBSTU campus's ground water and it is under tolerable limit. The As value of different season was studied to compare with the standard level. In dry season the mean value was $0.005 \mathrm{ppm}$ and in wet season it was $0.006 \mathrm{ppm}$ both were under the limit of standard level $(0.05 \mathrm{ppm})$ which indicates the water is fit for drinking purpose (Table 1).

\section{Correlation Studies}

Relationship among $\mathrm{P}^{\mathrm{H}}$ with TDS, EC, As, Fe, $\mathrm{Pb}$ and TDS with EC, As, Pb, Fe, Mn and EC with As, Fe, $\mathrm{Mn}$ and $\mathrm{As}$ with $\mathrm{Pb}, \mathrm{Fe} \mathrm{Mn}$ and $\mathrm{Pb}$ with $\mathrm{Fe} \mathrm{Mn}$ and Fe with Mn were performed to study the relationship.

Table 2. Relationships among different parameters with their value of correlation of coefficient as well as regression lines

\begin{tabular}{|c|c|c|c|}
\hline Parameters & Relationship type & Value of $\mathbf{r}$ & Regression equation \\
\hline $\mathbf{P}^{\mathrm{H}}$ and TDS & non significant and negative & $r=-0.25$ & $y=-64.30 x+66.91$ \\
\hline $\mathbf{P}^{\mathrm{H}}$ and $\mathrm{EC}$ & significant and negative & $r=-0.515$ & $y=-272.0 x+2276$ \\
\hline $\mathbf{P}^{\mathrm{H}}$ and $\mathrm{As}$ & non significant and positive & $\mathrm{r}=0.176$ & $y=0.005 x-0.028$ \\
\hline $\mathbf{P}^{\mathrm{H}}$ and $\mathbf{P b}$ & non significant and negative & $r=-0.09$ & $y=-5 E-05 x+0.000$ \\
\hline $\mathbf{P}^{\mathrm{H}}$ and Fe & significant and positive & $\mathrm{r}=0.31$ & $y=4.938 x-29.95$ \\
\hline TDS and EC & non significant and positive & $r=0.214$ & $y=1.464 x+119.5$ \\
\hline TDS and As & significant and positive & $\mathrm{r}=0.361$ & $y=6 E-05 x-0.010$ \\
\hline TDS and $\mathbf{P b}$ & significant and positive & $\mathrm{r}=0.483$ & $y=1 E-06 x-0.000$ \\
\hline TDS and Fe & non significant and negative & $r=-0.223$ & $y=-0.013 x+6.097$ \\
\hline TDS and Mn & non significant and positive & $\mathrm{r}=0.250$ & $y=0.009 x-1.350$ \\
\hline ECand As & significant and positive & $r=0.643$ & $y=6 E-05 x-0.020$ \\
\hline EC and Mn & non significant and positive & $\mathrm{r}=0.181$ & $y=0.003 x-0.612$ \\
\hline $\mathrm{EC}$ and $\mathrm{Fe}$ & non significant and positive & $\mathrm{r}=0.0316$ & $y=0.001 x+2.205$ \\
\hline As and $\mathbf{P b}$ & non significant and positive & $\mathrm{r}=0.443$ & $y=0.005 x+3 E-05$ \\
\hline As and Fe & significant and positive & $r=0.693$ & $y=238.7 x+1.384$ \\
\hline As and Mn & non significant and negative & $r=-0.248$ & $y=-52.92 x+1.268$ \\
\hline $\mathrm{Pb}$ and $\mathrm{Fe}$ & non significant and negative & $r=-0.07$ & $y=-2098 x+2.857$ \\
\hline $\mathrm{Pb}$ and $\mathrm{Mn}$ & non significant and negative & $r=-0.350$ & $y=-6286 x+1.363$ \\
\hline Fe and Mn & significant and negative & $r=-0.476$ & $y=-293 x+1.77$ \\
\hline
\end{tabular}




\section{Conclusion}

The study concluded that the drinking water of MBSTU campus contained acceptable amount of $\mathrm{pH}$, $\mathrm{EC}$, TDS, As and $\mathrm{Pb}$ but higher amount of $\mathrm{Fe}$ and $\mathrm{Mn}$ which exceeded the recommended limit for drinking water. So on the basis of heavy metal contamination the ground water of MBSTU campus is not fully safe for health.

The experiment was conducted to determine the $\mathrm{pH}$, $\mathrm{EC}$, TDS, As, $\mathrm{Fe}, \mathrm{Pb}$ and $\mathrm{Mn}$ content in water samples of ground water and their impacts on water quality at MBSTU campus. $\mathrm{pH}$ values of 12 samples ranged from 6.4-6.8 and their mean value was 6.6. The TDS value of the water sample ranged from 192.5-282 ppm and their mean value $243.66 \mathrm{ppm}$. The range of EC value ranged from 377.5-590 $\mu \mathrm{scm}^{-}$ 1 . Arsenic (As) concentration was recorded from 0.000183 to $0.015925 \mathrm{ppm}$ and the mean value was $0.005622 \mathrm{ppm}$. The range of Iron $(\mathrm{Fe})$ value was 0 5.618 the mean value was 2.7265. Lead $(\mathrm{Pb})$ concentration was recorded within the limit 0.00 $0.0006 \mathrm{ppm}$ and their average value was 0.0000062 ppm. Manganese $(\mathrm{Mn})$ concentration was recorded within the limit $0.07-3.825 \mathrm{ppm}$ and their average value was $0.97 \mathrm{ppm}$.

\section{References}

Ali, M. A. 2002. Public private priority for water resource management in Bangladesh water. Two billion people are dying for it. World environment 4pys 5 June 2003. Dept. Env. The Government of Bangladesh.

Azad, A. K. 2003. Impacts of Farakka Barrage on surface water resources in Bangladesh. World Environment Day 5 June, 2003. Report Dept. Environ., Govt. Bangladesh. Pp. 40-43.
Basher, M. A. 2005. Assessment of Metal pollution in different water sources of some selected areas of Matlab Upazilla. M.S. Thesis., Dept. Environ. Sci., Bangladesh Agri. Univ., Mymensingh.

Cheng, Z. Y.; Zheng and Green, A. 2004. Rapid multi-element analysis of ground water by high resolution inductively coupled plasma mass spectrometry. Anal Bio anal Chem. 379:113-118.

D. C. H. 1998. Dhaka Community Hospital. The Arsenic Problem in Bangladesh. An introduction to the country and its arsenic situation. Presented at Int. Conf. on Arsenic Pollution of Ground Water in Bangladesh. 812 February 1998. Dhaka pp. 27-30.

Khan, L. R.; Zaman M.W.; Zakir, M. H. and Nizam, U. V. 2000. Environmental impact of ground water abstraction in Barind area Bangladesh JH. Environ Sic., 9(2): 119-126.

Minton, G. R. 2002. Storm water Treatment: Biological, Chemical, and Engineering

Principles. G. Minton, Seattle, Washington, 416 pp.

Paul, N. C. 2004. Trace metal contamination in water environment of Dhaka Metropolitan city. M.S thesis, Dept. Environmental Sci. BAU, Mymensingh.

Rahaman, A. K. M. M.; Sattaar, M. A.; Baten, M. A. and Hossain, M. A. 2005. Contamination of Buriganga river waters. Bangladesh $J$. Environ. Sci., 11(2): 319-322.

Sattar, M. A. 1996. A Text of Environmental pollution part-I AKSAI RPI. Mymensingh. pp. 95-115. 